\title{
ODPOWIEDZIALNOŚĆ CYWILNA LEKARZA WETERYNARII W PRAWIE POLSKIM
}

\section{CIVIL LIABILITY REGARDING VETERINARY SURGEON UNDER POLISH LAW}

\begin{abstract}
STRESZCZENIE
Opracowania ma na celu dogłębne rozważenie zagadnienia związanego z ponoszeniem odpowiedzialności cywilnej przez lekarza weterynarii. Celem niniejszego artykułu jest ustalenie zasady odpowiedzialności cywilnej lekarza weterynarii, jako odpowiedzialności deliktowej bądź kontraktowej, a to w szczególności na podstawie artykułu 4 ustawy z dnia 21 grudnia 1990 roku o zawodzie lekarza weterynarii i izbach lekarsko-weterynaryjnych, który to określa prawne granice wykonywania zawodu lekarza weterynarii. Źródłem odpowiedzialności cywilnej lekarza weterynarii może być istniejące pomiędzy stronami zobowiązanie (najczęściej umowa zawarta pomiędzy lekarzem weterynarii a właścicielem zwierzęcia) lub czyn niedozwolony (tzn. postępowanie niezgodne $\mathrm{z}$ prawem, z zasadami etyki lekarza weterynarii lub z zasadami współżycia społecznego, prowadzące do wyrzą-
\end{abstract}


dzenia szkody właścicielowi zwierzęcia). Autor niniejszego artykułu wskazał konstrukcję jaką posłużył się ustawodawca oraz przedstawił zagadnienia związane z przesłankami odpowiedzialności cywilnej lekarza weterynarii. Pomimo „bardzo skromnej” regulacji ustawowej dotyczącej wykonywania zawodu lekarza weterynarii, autor artykułu mając na uwadze obowiązujący stan prawny wskazuje, że odpowiedzialność cywilna lekarza weterynarii na mocy ustawy o zawodzie lekarza weterynarii i izbach lekarsko-weterynaryjnych będzie opierała się na odpowiedzialności deliktowej, a to właśnie ze względu na art. 4 tejże ustawy.

\title{
Słowa kluczowe
}

Szkoda, odpowiedzialność deliktowa, odpowiedzialność cywilna, właściciel zwierzęcia.

\begin{abstract}
The study aims at profound consideration of the issue of liability borne by veterinary surgeon. The purpose of the presented article is to establish the rule of liability borne by veterinary surgeon as liability in tort or contractual liability pursuant to Article 4 of Veterinary Surgeon Profession and Medical and Veterinary Chambers Act from $21^{\text {st }}$ December, 1990 which legally delimits veterinary surgeon profession. The source of liability borne by veterinary surgeon may be mutual obligation (most often a contract concluded between veterinary surgeon and pet owner) or tort/delict non-compliance with law, rules of professional ethics or rules of social coexistence causing damage to pet owner. The author of presented article described the construction used by legislator and introduced issues regarding prerequisites of liability borne by veterinary surgeon. Regardless of "very simple" statutory laws concerning veterinary surgeon profession, the author of the article, in view of existing legal system, points that civil liability borne by veterinary surgeon pursuant to Veterinary Surgeon Profession and Medical and Veterinary Chambers Act shall be based on tortious liability with regard to Article 4 of aforementioned act.
\end{abstract}

\section{Keywords}

Damage, liability in tort, civil liability, pet owner. 


\section{WSTĘP}

Właściwą z natury rzeczy cechą każdej zorganizowanej społeczności jest, iż zarówno relacje między poszczególnymi jej członkami a tą społecznością, jak i między poszczególnymi jej członkami wzajemnie odbywają się w ramach wytworzonego i uznanego przez nią systemu normatywnego. Wewnętrzny normatywny system prawny funkcjonuje w trzech głównych wyodrębnionych przedmiotowo działach: prawa państwowego - prawa administracyjnego, prawa cywilnego i prawa karnego. Na pograniczu norm między systemem norm moralnych a systemem norm prawnych i odpowiedzialności prawnej stoi system norm i odpowiedzialności deontologiczno-korporacyjnej ${ }^{1}$.

Rodzaje odpowiedzialności na podstawie wyżej wymienionych działów prawa nie wyłączają się wzajemnie, gdyż ich podstawy są odmienne. W przypadku lekarzy weterynarii możliwa jest sytuacja w której lekarz weterynarii za określony czyn może ponieść odpowiedzialność karną, cywilną a nadto odpowiedzialność przed sądem lekarsko-weterynaryjnym.

Celem niniejszego opracowania jest rozważenie zagadnienia związanego z ponoszeniem odpowiedzialności cywilnej przez lekarza weterynarii. Opracowanie niniejszego zagadnienia jest tym bardziej niezbędne $\mathrm{z}$ uwagi na brak opracowań dotyczących wyżej wspomnianego zagadnienia. Artykuł 1 ustawy z dnia 21 grudnia 1990 roku o zawodzie lekarza weterynarii i izbach lekarsko-weterynaryjnych ${ }^{2}$ określa podstawy wykonywania zawodu lekarza weterynarii. Należy podnieść, iż celem będzie ustalenie zasady odpowiedzialności cywilnej lekarza weterynarii, jako odpowiedzialności deliktowej bądź kontraktowej, a to w szczególności na podstawie artykułu 4 wyżej wymienionej ustawy, który to określa prawne granice wykonywania zawodu lekarza weterynarii. Przedmiotem niniejszego opracowanie nie będą więc rozważania dotyczące odpowiedzialności

1 M. Filar, S. Krześ, E. Marszałkowska-Krześ, P. Zaborowski, Odpowiedzialność lekarzy i zakładów opieki zdrowotnej, Warszawa 2004.

2 Ustawa z dnia 21 grudnia 1990 r. o zawodzie lekarza weterynarii i izbach lekarsko-weterynaryjnych, tj. Dz. U. z 2009 r. Nr 93, poz. 767 ze zm. 
lekarza weterynarii wykonującego zawód w zakładzie leczenia dla zwierząt i określenia odpowiedzialności w ramach działania zakładu na mocy ustawy o zakładach leczniczych dla zwierzą ${ }^{3}$.

\section{PODSTAWY PRAWNE ODPOWIEDZIALNOŚCI LEKARZA WETERYNARII}

Źródłem odpowiedzialności cywilnej lekarza weterynarii może być istniejące pomiędzy stronami zobowiązanie (najczęściej umowa zawarta pomiędzy lekarzem weterynarii a właścicielem zwierzęcia) lub czyn niedozwolony (tzn. postępowanie niezgodne z prawem, z zasadami etyki lekarza weterynarii ${ }^{4}$ lub z zasadami współżycia społecznego, prowadzące do wyrządzenia szkody właścicielowi zwierzęcia). Niewykonanie lub nienależyte wykonanie zobowiązania przez lekarza weterynarii (dłużnika) powoduje powstanie odpowiedzialności kontraktowej, natomiast gdy do powstania szkody dochodzi niezależnie od istniejącego stosunku zobowiązaniowego, wtedy gdy rodzi ona dopiero stosunek zobowiązaniowy jako stosunek samoistny, możemy mówić o odpowiedzialności deliktowej5.

Jeżeli niewykonanie lub nienależyte wykonanie przez lekarza weterynarii zobowiązania jest jednocześnie czynem niedozwolonym może on odpowiadać na mocy art. 443 k.c. ${ }^{6}$ bądź na zasadzie odpowiedzialności kontraktowej bądź deliktowej, gdyż zachodzi wówczas zbieg odpowiedzialności kontrakto-

3 Ustawa z dnia 18 grudnia 2003 roku o zakładach leczniczych dla zwierząt, Dz. U. z 2004 r., Nr 11, poz. 95 ze zm.

4 Obecnie obowiązujące zasady etyki i deontologii weterynaryjnej zostały wprowadzone mocą uchwały Nr 3/2008/VII Nadzwyczajnego Krajowego Zjazdu Lekarzy Weterynarii z dnia 26 stycznia 2008 r. w sprawie uchwalenia Kodeksu Etyki Lekarza Weterynarii (KELW)., wyd. przez Warszawska Izba Lekarsko-Weterynaryjna, Warszawa 2009 roku. www.vetpol.org

5 W. Czachórski, A. Brzozowski, M. Safian, E. Skowrońska-Bocian, Zobowiązania, Warszawa 2007 rok, s. 97-99.

6 Ustawa z dnia 23 kwietnia 1964 - Kodeks cywilny; Dz. U. Nr 16, poz. 93 ze zm. 
wej z deliktową7. Ponadto można również zwrócić uwagę na odpowiedzialność jaką ponosiłby lekarz weterynarii na zasadzie quasi ex contracto, bądź quasi ex delicto, które były ujęte W systemie prawa rzymskiego ${ }^{8}$. W quasi ex contracto istotę odpowiedzialności ujęto inaczej niż przy odpowiedzialności kontraktowej węzeł obligacyjny zawiązywał się tutaj przez podjęcie czynności przez jedną osobę, a więc bez porozumienia stron, a najczęściej w ogóle bez wiedzy zainteresowanego. O takich rodzajach więzi obligacyjnej można byłoby mówić, gdy lekarz weterynarii udziela pomocy weterynaryjnej zwierzęciu, które zostało potrącone przez samochód, a jego właściciel nic nie wie o zaistniałym zdarzeniu. W prawie rzymskim, w sytuacjach gdy druga strona stosunku obligacyjnego zaaprobowała działanie gestora to negatorium gestio zmieniało się w zlecenie. Czynności gestora musiały dotyczyć spraw cudzych i to takich które nie wynikały z jego obowiązku. Ponadto takowe świadczenia na mocy quasi contractu dotyczyły również świadczenia bezpłatnych usług. Gestor mógł wystąpić o zwrot należnych wydatków a Dominus negotii dochodził od gestora rozliczenia.

Sytuacja przedstawia się zupełnie inaczej w przypadku odpowiedzialność quasi ex delicto. W systemie prawa rzymskiego o takiej sytuacji mówiono np. gdy sędzia który prowadził sprawę niewłaściwie i w ten sposób naraził jedną osobę na szkodę sam stawał się stroną w procesie za szkodę osoby pokrzywdzonej i na tej podstawie odpowiadał. Odpowiadał nie tylko gdy udowodniono mu zamiar, ale i gdy w postępowaniu nie wykazał roztropności. Reguły wyżej wskazanej odpowiedzialności dotyczyły również sytuacji dochodziło do wydania błędnego orzeczenia. Roszczenie o naprawienie szkody na podstawie quasi ex delicto przysługiwało również przeciw osobom, które na budynkach przylegających do dróg umieszczały lub zawieszały rzeczy, które mogło wyrządzić szkodę przechodniom. Podstawową zasadą tej odpowiedzialności było samo stworzenie zagrożenia. Odpowiadał ten kto zamieszkiwał w mieszkaniu, bez względu na to czy spowodował szkodę. Lekarz weterynarii ponosiłby od-

7 K. Kolańczyk, Prawo rzymskie, wydanie V, Warszawa 2001, s. 420-437.

8 W. Rozwadowski, Prawo rzymskie, Warszawa 1991, s. 162-202. 
powiedzialność na zasadach odpowiedzialności quasi ex delicto w sytuacji, w której jego działanie spowodowałoby szkodę, gdyby uwodniono mu zamiar działania na szkodę pokrzywdzonego (właściciela zwierzęcia) lub w przypadku gdyby nie wykazał się, jak to określano w prawie rzymskim, roztropnością i w związku z powyższym jego działanie lub zaniechanie działania doprowadziłoby do stworzenia stanu zagrożenia np. epidemiologicznego, gdyby nie postępowałby lub naruszał postanowienia ustawy z dnia 11 marca 2004 roku o ochronie zdrowia zwierząt oraz zwalczaniu chorób zakaźnych zwierząt ${ }^{9}$.

Wykonywanie zawodu lekarza weterynarii jest w Polsce poddane regulacjom kilku ustaw. Przede wszystkim należy odróżnić działania lekarza weterynarii powszechnego dostępu (leczenie zwierząt domowych, gospodarskich, wykorzystywanych w celach rozrywkowych, eksponowanych w zwierzyńcach i ogrodach zoologicznych itp.), od wykonywania zawodu lekarzy weterynarii, którzy zajmują się szeroko pojętą ochroną zdrowia publicznego w ramach działań Inspekcji Weterynaryjnej.

Artykuł 1 ustawy z dnia 21 grudnia 1990 roku o zawodzie lekarza weterynarii stanowi, iż „wykonywanie zawodu lekarza weterynarii polega na ochronie zdrowia zwierząt oraz weterynaryjnej ochronie zdrowia publicznego i środowiska, a w szczególności: 1) badaniu stanu zdrowia zwierząt; 2) rozpoznawaniu, zapobieganiu i zwalczaniu chorób zwierząt; 3) leczeniu zwierząt oraz wykonywaniu zabiegów chirurgicznych; 4) wydawaniu opinii i orzeczeń lekarsko-weterynaryjnych; 5) badaniu zwierząt rzeźnych, mięsa i innych produktów pochodzenia zwierzęcego; 6) sprawowaniu czynności związanych z nadzorem weterynaryjnym nad obrotem zwierzętami oraz warunkami sanitarno-weterynaryjnymi miejsc gromadzenia zwierząt i przetwarzania produktów pochodzenia zwierzęcego; 7) badaniu i ocenie weterynaryjnej jakości pasz i pasz leczniczych oraz warunków ich wytwarzania i dystrybucji; 8) stosowaniu produktów leczniczych weterynaryjnych wydawanych z przepisu lekarza weterynarii; 9) wydawaniu recept na produkty lecz- 
nicze, z wyłączeniem produktów leczniczych weterynaryjnych, które będą stosowane u zwierząt.

2. Za wykonywanie zawodu lekarza weterynarii uważa się także pracę na stanowiskach wymagających kwalifikacji lekarza weterynarii, określonych w odrębnych przepisach.

3. Zawód lekarza weterynarii może wykonywać osoba, która uzyskała prawo wykonywania tego zawodu."

Prawne granice jego wykonywania określa art. 4 tejże ustawy stanowiąc, iż „lekarz weterynarii obowiązany jest wykonywać zawód ze szczególną starannością, w oparciu o zasady etyki i deontologii weterynaryjnej". Ich przekroczenie eliminuje możliwość wyłączenia bezprawności działania naruszającego dobro osobiste na podstawie przesłanki działania w ramach porządku prawnego.

Odpowiedzialności lekarza weterynarii wobec właściciela zwierzęcia (będącego „pacjentem dla lekarza weterynarii”) zależy od łączącego lekarza weterynarii i właściciela zwierzęcia (opiekuna) stosunku prawnego. Należy zwrócić uwagę, iż przedmiotem odpowiedzialności jest zwierzę, które to na mocy art. 1 ust. 1 ustawy z dnia 21 sierpnia 1997 roku o ochronie zwierzą ${ }^{10}$ nie tylko zostało upodmiotowione, ale ustawa przede wszystkim określiła minimalne standardy dobrostanu zwierząt. Lekarz weterynarii odpowiada za wyrządzenie szkody wobec właściciela zwierzęcia. Artykuł 25 ustawy o zakładach leczniczych dla zwierząt używa określenia właściciel lub opiekun nazywając go później posiadaczem. To również właściciel na podstawie art. 25 ustawy z dnia 18 grudnia 2003 roku o zakładach leczniczych dla zwierząt, któremu to zakład leczniczy świadczy usługę weterynaryjną, jest uprawniony do uzyskania informacji o stanie zdrowia zwierzęcia, metodach leczenia, dających się przewidzieć skutkach ich zastosowania lub zaniechania oraz o przewidywanych kosztach usługi. Jednak specyfika zawodu lekarza weterynarii ze swej istoty oraz regulacje ustawowe zawarte $\mathrm{w}$ art. 1 ust.1 ustawy o ochronie zwierząt dają podstawy do twierdzenia, iż podmiotem odpowiedzialności jest zwierzę.

10 Tj. Dz. U. z 2003 r. Nr 106, poz. 1002 ze zm. 
Specyfika wykonywania zawodu lekarza weterynarii daje podstawy do takiego twierdzenia. Można poczynić takie stwierdzenia również z uwagi na to, iż ustawodawca w wyżej wymienionym artykule ustawy z dnia 21 sierpnia 1997 roku o ochronie zwierząt stwierdza, iż „zwierze jest istotą żyjącą zdolna do odczuwania cierpienia", której to człowiek, a tym bardziej lekarz weterynarii winien jest poszanowanie, ochronę i opiekę. Ponadto artykuł 15 ustęp 1 kodeksu Etyki Lekarza weterynarii stanowi, iż „lekarza weterynarii powinien cechować przyjazny i racjonalny stosunek do zwierząt". Nie bez znaczenia są tendencje ustawodawcze zmierzające do jeszcze większej ochrony zwierząt oraz poszanowania ich jako istot żywych. Nie mniej jednak w stosunkach cywilnych ${ }^{11}$ na podstawie kodeksu cywilnego zwierzęta są traktowane jako rzeczy ${ }^{12}$. Należy przyjąć, iż lekarz weterynarii będzie przez swoje bezprawne działanie lub zaniechanie wyrządzał szkodę właścicielowi czy też opiekunowi zwierzęcia.

Zaniechanie działania lekarza weterynarii, do którego jest on zobowiązany z pewnością będzie skutkowało odpowiedzialnością cywilną. Szczególny prawny obowiązek ciąży na lekarzu weterynarii, którego to wykonywanie zawodu lekarza weterynarii zgodnie art. 1 ustawy z dnia 21 grudnia 1990 roku o zawodzie lekarza weterynarii i izbach lekarsko-weterynaryj-

11 J.Białocerkiewicz, Status prawny zwierząt. Prawa zwierząt czy prawna ochrona zwierząt, Toruń 2005.

12 W Komentarzu do Kodeksu Cywilnego E. Skowrońska-Bocian (E. Skowrońska-Bocian, [w:] Kodeks cywilny, Komentarz do art. 1-449 ${ }^{10}$, K. Pietrzykowski, Warszawa 2011) podnosi iż na mocy ustawy o ochronie zwierząt przesądzona została kwestia czy zwierza jest rzeczą. Zgodnie z art. 1 tej ustawy, zwierzę jako istota żyjąca, zdolna do odczuwania cierpienia, nie jest rzeczą. Jedynie w sprawach nieuregulowanych w ustawie do zwierząt stosuje się odpowiednio przepisy dotyczące rzeczy. „Odpowiednie” stosowanie przepisów dotyczących rzeczy oznacza zdaniem autorki wyżej wspomnianego komentarza stosowanie takich przepisów z uwzględnieniem tego, ze zwierze jest istotą żyjącą, oraz, że człowiek winien mu jest poszanowanie, ochronę i opiekę. Przepisy dotyczące rzeczy znajdują przede wszystkim zastosowanie w odnie?/2012 sieniu do kwestii dotyczących sytuacji prawno rzeczowej zwierząt oraz obrotu nimi. 
nych polega na ochronie zdrowia zwierząt oraz weterynaryjnej ochronie zdrowia publicznego i środowiska.

\section{PRZESŁANKI ODPOWIEDZIALNOŚCI CYWILNEJ W OGÓLNOŚCI}

Powstanie odpowiedzialności cywilnej lekarza weterynarii jest uzależnione od zaistnienia łącznie trzech przesłanek, do których należą wina lekarza, szkoda i związek przyczynowy.

Na wstępie należy przyjrzeć się pojęciu usługi weterynaryjnej, z uwagi na to, iż zakres tego pojęcia określa ramy czynności które może podejmować lekarz weterynarii w ramach wykonywania zawodu mające na celu zachowanie, ratowanie lub poprawę zdrowia zwierząt i ich produkcyjności. Zatem czynności związane z wykonywaniem zawodu lekarza weterynarii wykraczające poza ramy usługi weterynaryjnej (wykonywane oczywiście zgodnie z zasadami techniki i wiedzy) mogą zostać uznane za bezprawne i przesądzać o odpowiedzialności lekarza weterynarii. Ustawa z dnia 18 grudnia 2003 roku o zakładach leczniczych dla zwierząt $\mathrm{w}$ art. 2 ust. 1 określa jakie czynności mieszczą się w pojęciu usługi weterynaryjnej oraz określa ją jako czynność mającą na celu zachowanie, ratowanie lub poprawę zdrowia zwierząt i ich produkcyjności. Artykuł 2 ust. 1 stanowi, iż czynność ta polega „W szczególności” na: 1) badaniu stanu zdrowia zwierząt; 2) rozpoznawaniu, zapobieganiu i zwalczaniu chorób zwierząt; 3) leczeniu zwierząt; 4) udzielaniu porad i konsultacji; 5) pielęgnacji zwierząt; 6) wydawaniu opinii i orzeczeń; 7) wykonywaniu czynności związanych z określeniem zdolności rozrodczych zwierząt i ich zaburzeń oraz biotechniką rozrodu; 8) wykonywaniu detalicznego obrotu produktami leczniczymi weterynaryjnymi, paszami leczniczymi oraz wyrobami medycznymi przeznaczonymi dla zwierząt, na zasadach określonych w odrębnych przepisach; 9) wykonywaniu badań laboratoryjnych i innych badań diagnostycznych, zwanym dalej „usługami laboratoryjnymi”. Z kolei w myśl art. 2 
ust. 2 tego aktu usługi weterynaryjne mogą być świadczone przez lekarza weterynarii posiadającego prawo wykonywania zawodu, z zastrzeżeniem art. 3, w ramach działalności zakładu leczniczego dla zwierząt. Artykuł 3 ustawy wymienia czynności, które może wykonywać technik weterynarii.

Pojęcie usługi weterynaryjnej oraz wymienienie przez ustawodawcę zakresu czynności mieszczących się w wyżej wymienionym pojęciu stanowi istotne zagadnienie związane $\mathrm{z}$ ponoszeniem odpowiedzialności cywilnej przez lekarza weterynarii. Ponadto, należy zauważyć, iż ustawodawca nie dokonał wymienia wszystkich czynności, pozostawiając ich katalog otwartym. Należy również podkreślić, iż określanie wyrażające cel tych czynności, czyli „mające zachowanie, ratowanie lub poprawę zdrowia zwierząt i ich produkcyjności" będzie miało istotne znaczenie przy ocenie tego działania bądź zaniechania prowadzącego do naruszenia zasad ostrożności czy szczególnej staranności. Ustawodawca dokonuje poprzez wyżej wymienione określenia, po raz kolejny podkreślenia istoty i założeń jakimi powinien kierować się lekarz weterynarii, podczas wykonywania zawodu.

\subsection{BEZPRAWNOŚĆ DZIAŁANIA \\ LUB ZANIECHANIA DZIAEANIA LEKARZA WETERYNARII}

Przed przystąpieniem do zagadnienia winy lekarza weterynarii, należałoby rozważyć problematykę związaną z jej uwarunkowaniem. Podstawowymi przesłankami winy, a więc warunkami postawienia sprawcy zarzutu z powodu jego zachowania się, jest bezprawność tego zachowania oraz jego przypisywalność ${ }^{13}$. Bezprawność jest obiektywną cechą zachowania się, jako stwierdzenie naruszenia przez to zachowanie porządku prawnego. Należy jednak podkreślić, iż w literaturze występuje również pogląd, iż bezprawność nie jest tylko kategorią obiektywną, lecz ma charakter monistyczny, czyli musi mieć wspólną

13 B. Lewaszkiewicz-Petrykowska, Wina jako podstawa odpowiedzialność z tytułu czynów niedozwolonych, t. 2, Łódź 1969, s. 88 
treść, właściwą dla całego systemu prawnego ${ }^{14}$. Źródłem wyżej wymienionych zasad są przepisy powszechnie obowiązujące, jak i nakazy i zakazy wynikające z zasad współżycia społecznego ${ }^{15}$. W przypadku ustalenia odpowiedzialności lekarza weterynarii problematyczne może być rozgraniczenie częściowo nakładających się na siebie: elementu obiektywnego winy oraz bezprawności. Nie nasuwa problemu takie zachowanie lekarza weterynarii, gdy bez jakiegokolwiek uzasadnienia łamie on tajemnicę zawodową ${ }^{16}$, mamy wtedy do czynienia $\mathrm{z}$ ewidentną bezprawnością jego zachowania. Natomiast, gdy swoim zachowaniem lekarz weterynarii narusza reguły i zasady medycyny weterynaryjnej, narusza swoje obowiązki zawodowe, wówczas stanowi to urzeczywistnienie obiektywnego elementu winy. Bezprawność zachowania lekarza może wynikać z braku zgody właściciela (opiekuna zwierzęcia), z braku celu leczniczego zabiegu weterynaryjnego, jak i z niezgodności zachowania lekarza weterynarii z podstawowymi i ogólnie przyjętymi w medycynie weterynaryjnej sposobami postępowania fachowego.

Na wstępie należy wskazać, iż ustawodawca w ustawie z dnia 21 grudnia 1990 roku o zawodzie lekarza weterynarii i izbach lekarsko-weterynaryjnych nie zawarł regulacji związanych obowiązkiem informowania właściciela zwierzęcia o planowanych działaniach, i uzyskania jego zgody na zabieg weterynaryjny. Uprawnienie do żądanie uzyskania informacji o stanie zdrowia zwierzeccia od lekarza weterynarii posiada właściciela zwierzęcia jedynie na podstawie art. 25 ustawy o zakładach leczniczych dla zwierząt. Niemniej jednak na podstawie wyżej wspomnianego artykułu tej ustawy lekarz weterynarii nie ma obowiązku informowania właściciela zwierzęcia o stanie zdrowia zwierzęcia. Ten obowiązek pojawia się dopiero, gdy informacji takiej zażąda właściciel zwierzęcia. Regulacje dotyczące

14 M. Sośniak, Bezprawność zachowania jako przestanka odpowiedzialności cywilnej, Kraków 1959, s. 102 i n.

15 G. Bieniek, [w:] Komentarz do Kodeksu Cywilnego, Księga Trzecia, Zobowiązania, t. 1, G. Bieniek i inni, Warszawa 2009, s. 377-383; G. Bieniek, Komentarz do art. 415 k.c, Lex, XI 2009.

16 Art. 28 Kodeksu Etyki Lekarza Weterynarii (KELW). 
obowiązku informowania właściciela zwierzęcia o stanie zdrowia zwierzęcia zawarte są w Kodeksie Etyki Zawodu Lekarza Weterynarii. Na przykład w art. 19 KELW zawarty jest obowiązek informowania właściciela zwierzęcia jak i obowiązek uzyskania jego zgody na działanie lecznicze. W tym miejscu należy podnieść, iż ustawodawca nie przewidział w obecnie obowiązujących przepisach prawa regulacji dotyczących obowiązku informowania właściciela zwierzęcia o stanie zdrowia zwierzęcia. Brak takowych regulacji należy ocenić jak najbardziej negatywnie, a nadto może budzić zdziwienia $\mathrm{z}$ uwagi na to, iż ustawodawca w ustawie z dnia 5 grudnia 1996 roku o zawodzie lekarza i lekarza dentysty ${ }^{17}$ zawarł szeroko rozbudowane regulacje dotyczące podstaw odpowiedzialności lekarzy oraz obowiązków na nich ciążących. Oczywistym jest, iż wyżej wymienione zawody rożni podmiot, na rzecz którego świadczona jest pomoc medyczna, niemniej jednak $\mathrm{w}$ pewnych zagadnieniach oba te zawody mają charakter zbliżony.

Bezprawnym zabiegiem będzie zabieg wykraczający przeciwko zasadom wiedzy i etyki lekarza weterynarii. Ponadto można w tym miejscu zwrócić uwagę na aspekt celu leczniczego zabiegu weterynaryjnego. Na pewno działaniem bezprawnym będzie takie działanie, które nie będzie przejawiało charakteru leczniczego. Z takim działaniem moglibyśmy mieć do czynienia gdyby to lekarz weterynarii dokonał zabiegu chirurgicznego w celu zweryfikowania swojej wiedzy lub w celu przeprowadzenia prawnie nieuregulowanego eksperymentu.

\subsection{WINA}

Wina to ujemna ocena całokształtu postępowania sprawcy, polegająca na możliwości uczynienia mu zarzutu na podstawie analizy jego stanu psychicznego i istniejącej normy ${ }^{18}$. Pojęcie

17 Ustawa z dnia 5 grudnia 1996 roku o zawodach lekarza i lekarza dentysty, tj. Dz. U. z 2011 r. Nr 277, poz. 1634 ze zm.

18 P. Machinowski, [w:] System prawa prywatnego, Prawo zobowiązań. 3/2012 Cześć Ogólna, Z. Banaszczyk, A. Brzozowski, M. Kaliński, P. Machnikowski, 
winy składa się z dwóch elementów obiektywnego i subiektywnego, które muszą wystąpić łącznie ${ }^{19}$.

W przypadku lekarzy weterynarii elementem obiektywnym ich winy w spowodowaniu szkody będzie najczęściej naruszenie obowiązujących przepisów lub reguł wynikających z zasad wiedzy medyny weterynaryjnej oraz doświadczenia i deontologii zawodowej. W przypadku zwierzyny łownej możliwa byłaby sytuacja w której to np. dochodzi do zdarzenia drogowego w wyniku którego ranna zostaje zwierzyna łowna, na mocy ustawy z dnia 13 października 1995 roku Prawo łowieckie ${ }^{20}$ można byłoby mówić o odpowiedzialności na zasadzie quasi ex contacto. W takiej sytuacji lekarz weterynarii może działać jako prowadzący cudze sprawy bez zlecenia np. gdy zastanie potracone zwierze łowne na drodze i podejmie on działania w celu ochrony zdrowia zwierzęcia przez wykonanie usługi weterynaryjnej. Należy wskazać, iż osobą która posiada wyłączne prawo podejmowania czynności lekarsko weterynaryjnych jest lekarz weterynarii. Powinien wówczas dołożyć należytej staranności tak jak gdyby została zawarta umowa. W razie wyrządzenia szkody ze swej winy ponosi odpowiedzialność kontraktową przy zbiegu $\mathrm{z}$ odpowiedzialnością deliktową ${ }^{21}$. W przypadku czynu niedozwolonego obiektywnym elementem winy będzie np. działanie wbrew woli właściciela zwierzęcia, odmowa udzielenia pomocy weterynaryjnej zwierzęciu oraz brak wskazania właścicielowi innego lekarza weterynarii, który mógłby jej udzielićn ${ }^{22}$.

Elementem obiektywnym winy jest naruszenie przez lekarza jego obowiązków zawodowych, czyli takich, które wynikają z przepisów, oraz tak i z istoty zawodu, jak i z postanowień zastrzeżonych w umowie z właścicielem zwierzęcia, jeżeli lekarz weterynarii prowadzi prywatna praktykę.

P. Mostowik, M. Pyziak-Szafnicka, A Śmieja, K. Zawada, F. Zoll. Red. A. Olejniczak, Warszawa 2009, tom 6, s. 403 i n.

19 Zob. np. W Czachórski, [w:] System, t. III, cz. 1, s. 539 i n.

20 Tj. Dz. U. z 2005 r. Nr 127, poz. 1066 ze zm.

21 W.Radecki,Prawołowieckie, Komentarz, wydanieII, Warszawa2008, s.45$-59,244$.

22 Obowiązek ten wynika z art. 20 Kodeksu Etyki Lekarza Weterynarii. 
Lekarz weterynarii musi nie tylko przestrzegać przepisów prawa, ale także norm moralny i zasad etyki zawodu lekarza weterynarii. Obecnie obowiązujące zasady etyki i deontologii weterynaryjnej zostały wprowadzone mocą uchwały $\mathrm{Nr}$ 3/2008/VII Nadzwyczajnego Krajowego Zjazdu Lekarzy Weterynarii z dnia 26 stycznia 2008 r. w sprawie uchwalenia Kodeksu Etyki Lekarza Weterynarii (KELW). Naruszenie przez lekarza postanowień kodeksu może stanowić element obiektywny winy.

Negatywna ocena zachowania lekarza weterynarii jako sprawcy szkody przybierająca postać zarzutu naruszenia porządku prawnego jest konieczną, ale nie wystarczająca przesłanką nałożenia na sprawcę obowiązku naprawienia szkody. Niezbędna jest tutaj ocena działania lub zaniechania z punktu widzenia sprawcy szkody do podjętego czynu. Można przyjąć, iż wina lekarza weterynarii może dotyczyć techniki weterynaryjnej (niewiedza lekarza weterynarii, niezręczność w trakcie wykonywania zabiegu, nieuwaga) oraz wina ta może właśnie nie dotyczyć techniki weterynaryjnej - opieki nad zwierzętami (nieuprzedzenie właściciela zwierzęcia o sposobie leczenia i o skutkach z nim związanych, przeprowadzenie zabiegu bez zgody właściciela zwierzęcia, itp.), wina lekarza weterynarii może polegać na działaniu lub zaniechaniu, gdy szkody można było uniknąć, gdyby lekarz weterynarii dochował należytej staranności.

Problem związany z oceną elementu subiektywnego stanowią stopnie winy. Można tutaj wyróżnić umyślność i nieumyślność (niedbalstwo i lekkomyślność). Stopnie te kryją w sobie wiele pośrednich gradacji. Nawet gdyby odróżnienia te nie miały dla odpowiedzialności deliktowej z art. 415 k.c. istotnego znaczenia, gdyż sprawca stanie się tu odpowiedzialny za każdy nawet lekki stopień winy, to przecież dla całości przepisów związanych z odpowiedzialnością odszkodowawczą kwestia ta nie jest objęta ${ }^{23}$.

Wina umyślna w postępowaniu lekarza weterynarii wydaje się występować niezwykle rzadko, a to z uwagi na samą istotę

23 W. Czachórski, A. Brzozowski, M. Safian, E. Skowrońska-Bocian, Zobowiązania, Warszawa 2009, s. 217 i n. 
zawodu i cel jego wykonywania. Niemniej jednak polegać ona może na świadomym działaniu sprzecznym z obowiązkiem lub na świadomym zaniechaniu, czyli np. niepodjęciu działania nakazanego w danym przypadku przez przepis prawa.

Znacznie większe wątpliwości pojawiają się w przypadku niedbalstwa i lekkomyślności. Zarówno przy niedbalstwie, jak i przy lekkomyślności sprawca naraża się na zarzut, na ocenę wadliwego działania. W przypadku lekkomyślności sprawca wyobraża sobie skutek, ale bezpodstawnie przypuszcza, ze go uniknie, a w przypadku niedbalstwa w ogóle nie wyobraża sobie skutku, choć może i powinien go sobie wyobrazić24. Wyłania się w związku z tym kwestia miernika staranności - wzorca z którym należy zestawiać zachowanie się sprawcy, by móc je ocenić jako nienależyte. Wydaje się, że taki wzorzec jest nie tylko niezbędny, a przede wszystkim niezwykle istotny. Współczesne systemy prawa cywilnego znają różne postacie takiego właśnie wzorca, niekiedy spersonalizowane jak np. „dobry ojciec” we francuskim kodeksie cywilnym ${ }^{25}$.

Taki właśnie wzorzec należałoby stworzyć również dla postępowań związanych z odpowiedzialnością cywilną lekarzy weterynarii. Wydaje się słuszne przyjęcie, iż niezręczność czy nieuwaga lekarza weterynarii nie może być traktowana jako ryzyko zabiegu ponoszone przez właściciela zwierzęcia. Tworzą one winę w przypadku, gdy przyjmowany jako wzorzec lekarza jest lekarz weterynarii zręczny, sumienny i uważny, który by ich w danych okolicznościach nie popełnił. Niedbalstwo polegać będzie na niedołożeniu wysokiej miary wiedzy i staranności ${ }^{26}$. W tym celu powinno się przyjąć miernik obiektywny i subiektywny. Polegać on powinien na porównaniu postępowania lekarza weterynarii wywołującego szkodę z pewnym wzorcem postępowania, uniezależnionym od indywidualnych właściwości

24 Z. Radwański, System Prawa Cywilnego. Zobowiązania. Część ogólna, Warszawa 1980, cz. I, §58.

25 Ibidem.

26 Obowiązek dołożenia wynika wprost z ustawy o zawodzie lekarza weterynarii i izbach weterynaryjnych, który to stanowi, iż lekarz weterynarii obowiązany jest wykonywać zawód ze szczególną starannością w oparciu o zasady etyki i deontologii. 
sprawcy, lecz przy uwzględnieniu pewnych elementów konkretnych, zewnętrznych dotyczących danego przypadku. Poprawne ocenienie postępowania sprawcy szkody wymagałoby umieszczenia abstrakcyjnego wzorca właśnie w tych konkretnych warunkach. Jeśli zachowanie odbiega od tego wzorca, można lekarzowi weterynarii przypisać winę.

Ponadto należy wskazać, iż lekarz weterynarii nie tylko jest zobowiązany do wykonywania zawodu z należytą starannością, ale także powinien posiadać należytą wiedzę i umiejętności zawodowe. Wzorzec ten jednak może się różnić w zależności od pewnych okoliczności sprawy. Wzorzec lekarza weterynarii jest dosyć elastyczny. Wzorzec ten może być uzależniony od wspomnianych wyżej okoliczności, i tak np. od tego czy jest lekarzem specjalistą $^{27}$, lekarzem weterynarii prowadzącym dobrze wyposażaną klinikę weterynaryjną, czy też gabinet weterynaryjny nieposiadający możliwości wykonania wszelkich badań oraz usług weterynaryjnych. Jednak lekarz weterynarii powinien spełniać pewne minimum wiedzy i staranności bez względu na miejsce wykonywania zawodu, czy też możliwości miejsca pracy i jego wyposażenia. Wzorzec ten jest również zależny od stanu wiedzy lekarza weterynarii i jest on związany z rozwojem wiedzy dotyczącym zwalczania i leczenia chorób zwierząt.

Lekarz weterynarii powinien na podstawie art. 5 ustawy o zawodzie lekarza weterynarii i izbach weterynaryjnych oraz na mocy art. 5 i 6 Kodeksu Etyki Zawodu Lekarza Weterynarii zaznajamiać się z nowymi technikami oraz wiedzą w dziedzinie medycyny weterynaryjnej, oraz powinien pogłębiać swoje umiejętności. Zgodnie $\mathrm{z}$ art. 5 ustęp 1 ustawy o zawodzie lekarza weterynarii i izbach weterynaryjnych lekarza weterynarii wykonującego zawód, u którego ujawniono niedostateczne przygotowanie zawodowe, okręgowa rada lekarsko-weterynaryjna może zobowiązać do odbycia przeszkolenia uzupełniającego pod rygorem utraty prawa wykonywania zawodu. A na mocy art. 5 ustęp 2 ustawy o zawodzie lekarza weterynarii i izbach weterynaryjnych wyżej wspomniany art. 5 ust 1 stosuje się odpowied-

27 Prawo takie przysługuje lekarzowi weterynarii na mocy art. 3 ustawy o zawodzie lekarza weterynarii i izbach lekarsko-weterynaryjnych. 
nio do lekarza weterynarii, który przerwał wykonywanie zawodu na okres dłuższy niż pięć lat. Ustawodawca wprowadza tutaj swoistą kontrolę wiedzy lekarzy weterynarii, którzy mogliby ją utracić np. z powodu nie wykonywania zawodu przez okres lat pięciu. Ponadto obowiązek znajomości i pogłębiania wiedzy z zakresu medycyny weterynaryjnej wynika również z art. 5 i 6 Kodeksu Etyki Lekarza Weterynarii ${ }^{28}$. Brak wiedzy więc stanowi także winę lekarza. Jednakże w przypadku braku stwierdzenia wyjątkowo rzadkiej występującej choroby (np. krętkowicy kleszczowej ${ }^{29}$ ) przez lekarza weterynarii, niewątpliwie trudnym byłoby przypisanie lekarzowi weterynarii winy oczywiście stosownie do okoliczności poszczególnego stanu faktycznego.

Wina lekarza weterynarii przejawiać się będzie zwykle pod postacią niedbalstwa. Winą będzie również postępowanie lekarza weterynarii oceniane ujemnie ze względu na naruszenie przez niego obowiązków zawodowych lub umownych albo ogólnych reguł ostrożności mimo, że niedbalstwem nie jest. Winą będzie nieprzeprowadzenie odpowiednich badań wstępnych, czego skutkiem może być błędna diagnoza lub zbędne leczenie albo wystąpienie rożnych komplikacji co naraża właściciela zwierzęcia na szkodę.

Kwestią konieczną do rozważenia jest czy w przypadku wykonywania zawodu lekarza weterynarii należy mówić o dołożeniu należytej staranności czy o zobowiązaniu rezultatu. Wspomnianą kwestię zdaje się przesądzać art. 4 ustawy o zawodzie lekarza weterynarii i izbach lekarsko-weterynaryjnych,

28 Art. 5 1. Lekarz weterynarii wykonuje swój zawód, opierając się na współczesnej wiedzy w zakresie medycyny weterynaryjnej, przestrzegając obowiązującego prawa i uchwał samorządu, ze szczególnym uwzględnieniem tego Kodeksu.2. Lekarz weterynarii ma obowiązek znać aktualny stan prawny w zakresie wykonywanego zawodu. Art. 6 1. Obowiązkiem lekarza weterynarii jest stałe uzupełnianie swojej wiedzy i doskonalenie umiejętności zawodowych. Pożądany jest też jego udział w działalności towarzystw naukowych oraz organizacji zawodowych.2. Lekarz weterynarii, w miarę swych możliwości, publikuje w prasie fachowej lub w innej formie upowszechnia własne spostrzeżenia przydatne $\mathrm{w}$ nauce i praktyce lekarsko-weterynaryjnej.

29 J. Beera, Choroby zakaźne zwierząt domowych: praca zbiorowa, t. 2, Choroby bakteryjne, mikozy, mikotoksykozy, przekł. zbiorowy pod red. nauk. H. Janowskiego, Warszawa 1980. 
w myśl którego lekarz weterynarii obowiązany jest wykonywać zawód ze szczególną starannością, w oparciu o zasady etyki i deontologii weterynaryjnej.

Ustawodawca zdaje się przesadzać i jednocześnie można stwierdzić, iż chodzi tutaj o staranność wysokiej miary, a to z uwagi na określenie „szczególna”. Ponadto należy zwrócić uwagę, iż z samej istoty zawodu oraz zasad jego wykonywania należałoby wnioskować iż lekarze weterynarii wybierając swój zawód kierują się właśnie przesłankami opieki nad zwierzętami w jak najwyższym stopniu. Ponadto wszelkie wskazania ustawodawcy zawarte w art. 5 i 6 ustawy o zawodzie lekarza weterynarii i izbach lekarsko-weterynaryjnych podkreślają wymóg wysokiej wiedzy i fachowości. Lekarze weterynarii podlegają swoistej kontroli okręgowej rady lekarsko-weterynaryjnej pod względem posiadanej przez nich wiedzy czy doświadczenia w zawodzie. Obowiązek wykonywania zawodu ze starannością wysokiej miary nakłada już na lekarza weterynarii Kodeks Etyki Lekarza Weterynarii. Analiza poszczególnych przepisów wyżej wymienionego kodeksu dotyczących wymogów związanych z pogłębianiem wiedzy weterynaryjnej, informowaniem właściciela zwierzęcia o przebiegu leczenia, czy innych kwestii związanych z procesem leczenia oraz kontroli osób mających wpływ na leczenie zwierzęcia może prowadzić do jak najbardziej uzasadnionego twierdzenia, iż obowiązek lekarza weterynarii wykonywania usług weterynaryjnych, powinien być podjęty ze starannością wysokiej miary.

\subsection{ZWIĄZEK PRZYCZYNOWY}

Przyjęcie winy przez lekarza weterynarii nie stanowi jeszcze o jego odpowiedzialności. Pomiędzy zachowaniem lekarza weterynarii a szkodą musi zajść związek przyczynowy. Ciężar udowodnienia związku przyczynowego spoczywa na poszkodowanym. W praktyce może to okazać się trudne, a to $\mathrm{z}$ uwagi na to, iż na szkodę mogło się złożyć szereg przyczyn ${ }^{30}$. W wie-

30 W. Czachórski, op. cit., s. 222 i n. 
lu przypadkach zaistnienie związku przyczynowego może być oczywiste, do takiej sytuacji może np. dojść gdy po operacji stan zwierzęcia nagle się pogorszy, wskutek czego nastąpi długotrwała choroba zwierzęcia lub gdy zwierzę padnie, a to z powodu pozostawienia narzędzia w polu operacyjnym, czy też w przypadku nie zastosowania sterylnych narzędzi operacyjnych i w wyniku tego wywołania infekcji. W przypadku pogorszenia się stanu zdrowia zwierzęcia po zabiegu to po stronie właściciela zwierzęcia, który będzie żądał naprawienia szkody czy też zadośćuczynienia stoi obowiązek wykazania związku przyczynowego pomiędzy nienależytym działaniem lub zaniechaniem działania lekarza weterynarii a szkodą jaką doznał poszkodowany.

Związek przyczynowy pełni w prawie cywilnym funkcję przesłanki odpowiedzialności odszkodowawczej. Związek przyczynowy wyznacza ponadto granice odpowiedzialności odszkodowawczej w tym zakresie, iż zobowiązany ponosi odpowiedzialność tylko za normalne następstwa swego postępowania lub zdarzeń, z którymi ustawa łączy obowiązek odszkodowawczy $^{31}$. W związku z powyższym skutki pozostające poza granicami adekwatnej przyczynowości nie są objęte takim obowiązkiem $^{32}$.

Lekarz weterynarii nie będzie odpowiadał za nadzwyczajne, niemożliwe do przewidzenia komplikacje oraz za inne nie pozostające $\mathrm{w}$ normalnym związku przyczynowym $\mathrm{z}$ jego postępowania skutki. Ponadto można stwierdzić, iż najczęściej występującym związkiem przyczynowym będzie działanie lekarza weterynarii i powstała stąd szkoda, nie można też zapominać o przypadku $\mathrm{w}$ którym lekarz weterynarii zaniecha działania i w związku z tym zaniechaniem powstanie szkoda. Powyższa sytuacja może mieć miejsce chociażby w przypadku, gdy lekarz weterynarii nie skieruje właściciela zwierzęcia do specjalisty,

31 Z. Banaszczyk, [w:] Kodeks cywilny, Komentarz do artykułów 1-44910, Z. Banaszyk, A. Brzozowski, J. Mojak, L. Ogiegło, M. Pazdan, J. Pietrzykowski, W. Popiołek, M. Safian, E. Skowrońska-Bocian, K. Zaradkiewicz, K. Zawada, red. K. Pietrzykowski, t. 1, Warszawa 2011, s. 1331-1335

32 A. Szpunar, Odszkodowanie za szkodę majątkową. Szkoda na mieniu i osobie, Bydgoszcz 1998, s. 15-16. 
bądź gdy nie wykona on na zwierzęciu przed dokonaniem zabiegu koniecznych badań wstępnych. W takim przypadku możemy mówić o przyczynowości zaniechania.

Adekwatny związek przyczynowy między zachowaniem się lekarza weterynarii a powstałą szkodą może przybrać charakter bezpośredni lub pośredni. Rzeczą najważniejszą jest jednak, aby skutek zachowania się lekarza powstał w granicach normalnego związku przyczynowego. Wystarczającym jest, aby związek przyczynowy był pośredni pomiędzy zachowaniem lekarza weterynarii a szkodą jaka została wyrządzona właścicielowi zwierzęcia. Powyższa sytuacja może mieć miejsce np. w sytuacji gdy brak natychmiastowego działania przyczynił się do zmniejszenia szans na poprawę stanu zdrowia zwierzęcia. Na powstanie szkody może mieć wpływ wiele czynników dlatego, należy ustalić w jakim stopniu prawdopodobieństwa wobec innych czynników pozostaje niedbalstwo lekarza.

\subsection{SZKODA}

W prawie cywilnym szkoda jest podstawą odpowiedzialności odszkodowawczej33. Szkodą jest każdy uszczerbek, który dotyka poszkodowanego, zarówno o charakterze majątkowym jak i niemajątkowym ${ }^{34}$. Szkodą majątkową jest powstała wbrew woli poszkodowanego różnica między obecnym stanem majątkowym a tym stanem jaki zaistniałby, gdyby nie nastąpiło zdarzenie wywołujące szkodę ${ }^{35}$. Pojęcie szkody w mieniu odnosi się bezpośrednio do składników majątku poszkodowanego. Szkoda na osobie natomiast odnosi się bezpośrednio do osoby poszkodowanego, jest bowiem konsekwencją naruszenia jego dóbr osobistych. Przykładami szkody na mieniu mogą być uszko-

33 Z. Banaszczyk, [w:] op. cit., s. 1335 i n.; zob. także T. Wiśniewski, [w:] Komentarz do kodeksu cywilnego, Księga Trzecia, Zobowiązania, red. G. Bieniek, Warszawa 2003, s. 62-63.

34 Ibidem.

35 Orzeczenie Sądu Najwyższego z dnia 11 lipca 1957 roku, 2 CR 304/07, OSN 1958, nr III poz. 76; orzeczenie Sadu Najwyższego z dnia 22 listopada 1963 roku, III PO 31/63, OSNCP 1964, z. 7-8, poz. 128. 
dzenie rzeczy lub jej zniszczenie. Przykładem szkody na osobie może być uszkodzenie ciała, naruszenie czci. Z takim zdarzeniem może wiązać się ból fizyczny czy też ujemne przeżycia psychiczne $^{36}$. Szkoda majątkowa w świetle przepisów kodeksu cywilnego może obejmować, po pierwsze straty jaką doznaje poszkodowany wskutek doznania szkody - czyli ubytek w jego majątku (szkoda rzeczywista - damnum emergens), a po drugie może ona obejmować utratę korzyści (lucrum cessans), jakiej poszkodowany mógłby się spodziewać gdyby wyżej wspomnianej szkody nie doznał.

Przenosząc powyższe rozważania teoretyczne potrzeby tegoż artykułu należy zwrócić uwagę, iż szkodą jaką może wywołać lekarz weterynarii jest śmierć zwierzęcia, która nastąpiła w wyniku niedbalstwa podczas operacji bądź nieprzekazania zwierzęcia „lekarzowi weterynarii-specjaliście”. Szkoda występuje tutaj jak w majątku poszkodowanego, którym to jest właściciel zwierzęcia. Może ona przyjąć formę ubytku w majątku poszkodowanego (właściciela zwierzęcia) np. w wyniku błędu lekarza padł ogier rozpłodowy, którego wartość na rynku handlarzy koni była bardzo wysoka, a nadto przysługuje właścicielowi zwierzęcia również możliwość dochodzenia odszkodowania w ramach utraconych pożytków wzorując się dla przykłady wyżej wspomnianego właściciela z powodu braku reproduktora. W związku z powyższym właściciel mógł utracić również źródło zarobku, którym było np. krycie klaczy.

Zdecydowanie większy problem $\mathrm{w}$ doktrynie stanowi zagadnienie krzywdy. Zadośćuczynienie stanowi formę rekompensaty pieniężnej z tytułu szkody niemajątkowej. Podstawą żądania $\mathrm{z}$ art. 445 k.c. jest doznana krzywda niemajątkowa w postaci ujemnych przeżyć związanych z cierpieniami psychicznymi i fizycznymi poszkodowanego wynikającymi z naruszenia dóbr osobistych wskazanych $\mathrm{w}$ tym przepisie ${ }^{37}$. Zadośćuczynienie nie może być jednak przyznane $\mathrm{z}$ powodu ujemnych przeżyć psychicznych wywołanych uszczerbkiem majątkowym, wyni-

36 W. Czachórski, op. cit., s. 88-97.

37 Wyrok Sadu Najwyższego z dnia 4 lipca 1969 roku, I PR 178/69, OSNC 1970, nr 4, poz. 71 z glosą A. Szpunara, PiP 1970, z. 8-9, s. 412. 
kających z naruszenia dóbr niemajątkowych, np. żal z powodu utraconego zarobku. Różnica pomiędzy krzywdą doznaną z powodu naruszenia dóbr wskazanych w art. 445, a wynikająca z innych powodów może być niekiedy trudna do przeprowadzenia. Należy jednak uznać za trafne stanowisko skłaniające się do szerszej wykładni rozstroju zdrowia jako stanu obejmującego również stany poważnego rozstroju psychicznego spowodowanego zdarzeniami z którymi łączy się odpowiedzialność w sferze odpowiedzialności deliktowej ${ }^{38}$. Zadośćuczynienie powinno jak najbardziej przysługiwać właścicielowi zwierzęcia w przypadku działania, bądź zaniechania lekarza weterynarii, które doprowadziło do tego, ze owe zwierze padło. Powyższe zdarzenie może u właściciela zwierzęcia jak najbardziej wywołać silne negatywne przeżycie psychiczne, a to z uwagi na silna więź łączącą go z ze zwierzęciem. Nadto należy wskazać, iż wprowadzenie szerszej wykładni rozstroju zdrowia wydaje się być jak najbardziej uzasadnione, a to $\mathrm{z}$ uwagi na wole ustawodawcy, który w art. 1 ustęp 1 i 3 ustawy z dnia 21 sierpnia 1997 roku o ochronie zwierząt podkreśla upodmiotowienie zwierząt oraz zwraca uwagę na to, iż zwierzę także czuje, a człowiek jest mu winien poszanowanie, ochronę i opiekę. Należy również wskazać, iż kwestia podmiotowości i związku emocjonalnego pomiędzy zwierzęciem a jego właścicielem była przedmiotem rozstrzygnięć sądów niemieckich i francuskiej, w związku z postępowaniem rozwodowym i kwestią powierzeniu jednemu z małżonków zwierzęcia. Pomimo wzięcia pod uwagę, tego, iż zwierzę „jest istotą i ma uczucia” oraz relacji łączącej właściciela z zwierzęciem zarówno w doktrynie, jak i w orzecznictwie wyrażono stanowisko, iż zbyt daleko idącym rozwiązaniem byłaby próba pozytywnej sądowej regulacji kontaktów oraz rozstrzygania o powierzeniu jednemu z małżonków zwierzęcia na wzór styczności z dzieckiem. Jednakże, co warte podkreślenia, zarówno judykatura jak i doktryna niemiecka i francuska jed-

38 M. Safian, [w:] Kodeks cywilny, Komentarz do artykutów 1-449¹0, Z. Banaszyk, A. Brzozowski, J. Mojak, L. Ogiegło, M. Pazdan, J. Pietrzykowski, W. Popiołek, M. Safian, E. Skowrońska-Bocian, K. Zaradkiewicz, K. Zawada, red. K. Pietrzykowski, t. 1, Warszawa 2011, s. 1731-11735. 
noznacznie podkreślały stanowisko, iż zwierzę jest istotą która posiada uczucia, a w związku z tym może nastąpić nawiązanie silnych relacji z właściciela ze zwierzęciem ${ }^{39}$. Argumentacja dotycząca uznania relacji łączącej właściciela zwierzęcia i zwierzę i jej charakteru zdaje się przesadzać o możliwości doprowadzenia z powodu straty „członka rodziny” (zwierzęcia) do rozstroju zdrowia spowodowanego silnym przeżyciem psychicznym, a przez to do możliwości dochodzenia roszczeń w tym zadośćuczynienia przed sądem.

\subsection{PRZYCZYNIENIE SIĘ POSZKODOWANEGO}

O przyczynieniu poszkodowanego mówimy, gdy w rozumieniu przyjętej w art. 361 k.c. koncepcji związku przyczynowego zachowanie się poszkodowanego może być uznane za jedno z ogniw prowadzących do ostatecznego skutku w postaci szkody ${ }^{40}$. Zachowanie się poszkodowanego z reguły powinno mieć charakter zawiniony, gdy odpowiedzialność sprawcy szkody opiera się na zasadzie winy. Im większy stopień winy po stronie poszkodowanego tym mniejsze będzie odszkodowanie. W przypadku ustalenia winy poszkodowanego należy porównać jego zachowanie z pewnym wzorcem postępowania i ustalić czy w danych okolicznościach tak postąpiłaby osoba rozważna. W przypadku właściciela zwierzęcia powinno się wziąć pod uwagę pewien wzorzec zachowania dla właściciela zwierzęcia. Inaczej powinno się traktować zachowanie właściciela zwierzęcia domowego, a inaczej właściciela - hodowcy posiadającego fachową wiedzę w dziedzinie żywienia i opieki nad zwierzęciem. O sytuacji, w której poszkodowany - właściciel zwierzęcia przyczyniłby się do powstania szkody można mówić w przypadku gdyby zbyt długotrwałe stosowanie leku przepisanego przez lekarza weterynarii wywołałoby szkodę w postaci powikłań związanych ze stosowaniem długotrwałym leku, a pomimo

39 T. Justyński, Prawo do kontaktów z dzieckiem w prawie polskim i obcym, Toruń 2011, s. 103-109.

40 W. Czachórski, op. cit., s. $248-250$. 
to właściciel zwierzęcia bez konsultacji z lekarzem podawałby lek dalej zwierzęciu. O takim przyczynieniu się można mówić z pewnością z uwagi na to, iż właściciel zwierzęcia sam zobowiązany jest na mocy art. 1 ust. 1 ustawy o ochronie zwierząt do jego poszanowania, opieki i ochrony. Ponadto właściciele zwierząt są uprawnieni do uzyskania informacji o całym procesie leczenia, jego rokowaniach, a także o tym gdyby dana usługa weterynaryjna nie mogła być świadczona w zakładzie leczniczym istnieje obowiązek wskazania innego zakładu leczenia dla zwierząt po stronie poprzedniego, takie uprawnienia jak i również zobowiązania wynikają z art. 25 i 26 ustawy o zakładach leczniczych dla zwierząt.

Przypadki związane z przyczynieniem się właściciela zwierzęcia, a tym bardziej właściciela będącego hodowcą, powinny występować niezwykle rzadko, a to z uwagi na to, iż właściciel zwierzęcia w czasie leczenia zwierzęcia powierza je pod opiekę całkowicie lekarzowi weterynarii. Nie wystąpi przyczynienie się z pewnością, gdy właściciel zwierzęcia choć z pewnymi wahaniami, jednak stosuje się do błędnej diagnozy lekarza weterynarii. Należy jednak na pewno uznać za przyczynienie się poszkodowanego do powstania szkody takie zachowanie, które będzie polegało na nieprzestrzeganiu zaleceń lekarza dotyczących prawidłowego żywienia zwierzęcia w danym przypadku, niezgłaszaniu się wraz z zwierzęciem na badania kontrolne lub niepowiadomieniu lekarza weterynarii $\mathrm{w}$ odpowiednim czasie o jakichkolwiek komplikacjach czy też nowych objawach. W wyżej wymienionej sytuacji będziemy mieli do czynienia w szczególności w przypadku, gdy właścicielem zwierzęcia jest hodowca, który w wielu przypadkach posiada znaczną wiedzę na temat występujących chorób u danego gatunku zwierzęcia oraz rasy, której hodowlą się zajmuje.

\section{ZAKOŃCZENIE}

Szeroka działalność organizacji działających na rzecz ochrony praw zwierząt doprowadziła do zmiany świadomości 
społeczeństwa $\mathrm{w}$ zakresie poszanowania praw zwierząt oraz możliwości ich ochrony. Konsekwencją powyższego działania organizacji ochrony zwierząt są obecne regulacje polskiego ustawodawcy ${ }^{41}$, które to zmierzają do zwiększanie wymogów dotyczących ochrony praw zwierząt. Obecny stan prawny oraz szereg kampanii społecznych z pewnością będzie prowadził do jeszcze większej świadomości właścicieli zwierząt w zakresie ochrony praw ich podopiecznych (zwierząt) oraz możliwości dochodzenia roszczeń odszkodowawczych również wobec lekarzy weterynarii. Niemniej jednak należy pamiętać, iż pomimo tego, że zgodnie art. 1 ustawy o ochronie zwierząt zwierzęta są istotami żyjącymi, zdolnymi do odczuwania cierpienia i nie są rzeczami to jednak nie może to prowadzić do kuriozum, w którym to lekarze weterynarii ponosiliby taką samą odpowiedzialność za swoje nienależyte działanie wobec właścicieli zwierząt jak lekarze medycyny wobec swoich pacjentów. Działania ustawodawcy powinny być obecnie tym bardziej rozważne, aby nie doprowadzić do stanu, w którym to prawa zwierzą byłyby interpretowane zbyt rozszerzająco. Należy pamięć, iż pomimo przesądzenia przez prawodawce polskiego o szczególnym statusie prawnym zwierząt trzeba podkreślić, iż art. 1 ustawy o ochronie praw zwierząt stanowi również, że sprawach nieuregulowanych w ustawie do zwierząt stosuje się odpowiednio przepisy dotyczące rzeczy.

Pomimo „bardzo skromnej” regulacji ustawowej dotyczącej wykonywania zawodu lekarza weterynarii, należy wywieść wniosek, iż odpowiedzialność cywilna lekarza weterynarii na mocy ustawy o zawodzie lekarza weterynarii i izbach lekarsko-weterynaryjnych będzie opierała się na odpowiedzialności deliktowej, a to właśnie ze względu na art. 4 tejże ustawy.

Kontakt e-mail: young10@op.pl

41 Ustawa z dnia z dnia 16 września 2011 r. o zmianie ustawy o ochronie zwierząt oraz ustawy o utrzymaniu czystości i porządku w gminach, Dz. U. z 2011 r. Nr 230, poz. 1373. 